\title{
Plasmatic adipocyte biomarkers and foot pain associated with flatfoot in schoolchildren with obesity
}

Ahmad H. Alghadir ${ }^{1}$

(iD) Sami A. Gabr ${ }^{1}$

(iD) Ashraf A. Rizk²

1. Rehabilitation Research Chair, College of Applied Medical Sciences, King Saud University, Riyadh, KSA. 2. Department of Biomechanics \& Motor Behavior, College of Sport Sciences \& Physical Activity, King Saud University, Riyadh, KSA.

\section{SUMMARY}

OBJECTIVE: The aim of this study was to determine the potential association of foot pain and plasmatic adipocytes as physiological biomarkers of childhood obesity with the incidence of flatfoot in a cohort of Egyptian school children aged 6 -12 years.

METHODS: A total of 550 Egyptian schoolchildren (220 boys and 330 girls) aged 6-12 years were randomly invited to participate in this descriptive survey analysis. For all children, we assessed the diagnosis and severity of flatfoot as well as plasma adipocytes, as well as adiponectin, leptin, resistin, IL-6, and TNF- $\alpha$, using the Dennis method and immunoassay techniques respectively. Foot pain was assessed by using a standard VAS of $100 \mathrm{~mm}$ and Faces Pain Scale, respectively.

RESULTS: Flat foot was predicted in 30.4\% of school-age children, most of them showed a higher frequency of overweight (33.3\%) and obesity (62.5\%). Boys showed higher ranges of flat foot than girls. Foot pain significantly correlated with flat foot and obesity among the studied populations. In overweight-obese children, plasmatic adipocyte variables, as well as adiponectin, leptin, resistin, IL-6, TNF- $\alpha$ showed significant correlations with foot stance, especially in boys. Also, the studied adipocyte variables along with BMI, age, gender explained about $65 \%$ of the variance of flatfoot with pain among our school-age students.

CONCLUSION: Foot pain showed an association with flat foot and childhood obesity in 30.4\% of school-age students (6-12 years). Foot pain was shown to correlate positively with the incidence of flat foot and changes in adiposity markers, as well as adiponectin, leptin, resistin, II-6, TNF- $\alpha$.

KEYWORDS: Flatfoot. Pediatric Obesity. Foot Diseases. Biomarkers. Obesity/complications. 


\section{INTRODUCTION}

Childhood is frequently associated with deformities in the lower extremities. ${ }^{1}$ In children, flexible or flat feet are the most (90\%) frequent foot problems. ${ }^{2}$ These abnormalities result in other feet complications such as gait disorders, foot depression, poor foot function, severe musculoskeletal pathologies, and a negative effect on the quality of life. ${ }^{1-4} \mathrm{~A}$ limited ankle joint range of motion with a higher risk of foot pain, knee pain, foot injury, stress fracture, abnormal gait, and poor exercise performance were associated with flat foot, particularly in children. ${ }^{4-7}$

In children with obesity, higher frequency of flatfoot was reported compared to those of normal weight. ${ }^{7-9}$ Also, weight-bearing or obesity increases pressure on the plantar area, which consequently produces an increase in foot length, width, and as a result, a change in foot size. ${ }^{8-10}$

In obese adolescents, higher levels of visfatin, leptin, and lower adiponectin concentrations were evaluated compared to their healthy counterparts..$^{8-13}$ Also, subjects with obesity showed an increase in the levels of tumor necrosis factor- $\alpha$ (TNF- $\alpha$ ) and interleukin-6 (IL-6) as pro-inflammatory markers. ${ }^{11-13} \mathrm{In}$ addition, leptin and resistin as biomarkers of childhood obesity showed a correlation with bone mineral density (BMD) and bone mineral content (BMC) of the femoral neck and lumbar spine, ${ }^{12-17}$ thus playing a significant role in mediating the foot-bone axis. After considering the aforementioned studies, ${ }^{8-15}$ the aim of this study was to determine the potential association of foot pain and plasmatic adipocytes as physiological biomarkers of childhood obesity with the incidence of flatfoot in a cohort of Egyptian school children aged 6 -12 years.

\section{METHODS}

\section{Subjects}

This cross-sectional study included a total of 550 Egyptian schoolchildren (boys $n=220$ and girls $n=330$ ) aged 6-12 years who were randomly invited in September 2014 and June 2015 from different elementary and Prep public schools in Mansoura, Egypt, to participate in this descriptive survey analyses. Children with muscle weakness, paralysis, intellectual disability, endocrine and cardiovascular disorders, congenital abnormalities below the level of the ankle, cerebral palsy, history of surgery, and musculoskeletal or neurologic diseases were excluded from this study. The demographic and clinical data of the participants are in Table (1).

\section{Anthropometric measurements}

Based on the BMI cut off criteria previously devolved by Cole et al. ${ }^{16}$ and specific to age and gender, the participants in the study were divided into four categories: underweight (BMI; > $\left.16.2 \mathrm{~kg} / \mathrm{m}^{2}\right)$, normal weight (BMI; $16.2-17.3 \mathrm{~kg} / \mathrm{m}^{2}$ ), overweight (BMI; 17.4 $\left.-21.45 \mathrm{~kg} / \mathrm{m}^{2}\right)$, and obese $\left(\mathrm{BMI} ; \geq 22 \mathrm{~kg} / \mathrm{m}^{2}\right)$. In addition, waist-to-height ratio (WHtR) was also calculated according to Ashwel et al. ${ }^{17}$ and other authors. ${ }^{18-22}$

\section{Assessments of adipocytokines}

ELISA kits specific for leptin and resistin were used to estimate adipocytokines in plasma samples of all the participants. Also, IL-6 and TNF- $\alpha$ Cytokines production in plasma samples was evaluated with an ELISA assay kit (EndogenTema, USA).

\section{Assessment of Flat foot}

Flat foot was significantly estimated by a welltrained trauma physician and orthopedist by using a classic wooden podoscope $(60 \times 40 \times 40 \mathrm{~cm})$. Finally, based upon Denis measurements, children who displayed second- and third-grade plantar footprint were well-defined as flatfooted. ${ }^{20}$

Foot pain was assessed by using a standard validated VAS of $100 \mathrm{~mm} .{ }^{21}$ Due to the conceptual complexity required to understand VAS, especially for younger ages, ${ }^{22,23}$ VAS scores of our subjects with ages below eight years were standardized based on a pre-validated Faces Pain Scale. ${ }^{19-24}$

\section{Statistical analysis}

The statistical SPSS software for Windows v.20 package was used to calculate frequencies of the studied variables. Both ANOVA and Dunnett post hoc test was used to compare the data between groups. The $\chi^{2}$ test was applied to determine the statistical association between the studied variables; the data were considered significant at $\mathrm{p}<0.05$ with 95\% CI.

\section{RESULTS}

The study sample was comprised of 550 school-age students, 220 boys, and 330 girls (60\%). Mean age was $10.1 \pm 0.3$ years; $p=0.11$ for boys and $p=0.50$ for girls. The participants were classified, based on BMI, into four groups. Abnormal body weight was reported 
in $240(43.6 \%)$ of the subjects; they were classified into low weight (4.16\%), overweight (33.3\%), and obese (62.5\%) (Table 1).

In this study, flatfoot was estimated in $30.4 \%$ $(\mathrm{n}=167$ ), higher in boys than in girls (boys: 32.27 , girls: $28.8 \%$; $p=0.01)$ up to the age of 10 years $(16.9 \%)$, without difference in the prevalence rates with respect to age $(p=0.21)$, as shown in figure $(1 \mathrm{~A})$, and figure (1B). The prevalence of flatfoot peaked at 6,7 , and eight years old for both boys and girls. The prevalence of flatfoot in schoolchildren aged seven and eight years was significantly higher (all $\mathrm{P}=0.001$ ) than in older children, regardless of gender (Figure 1B).

In addition, compared to subjects with normal weight, higher significant rates of flatfoot were reported in subjects with obesity $(52 \%, \mathrm{P}=0.001)$, overweight (31.25\%, $\mathrm{P}=0.01)$, and low weight (33.3\%, $\mathrm{p}=0.01$ ), respectively, as seen in the figure (1C).

Foot pain was shown to increase in overweight and obese children with flat foot compared to children with normal weight (Figure 1A \& 1B). Foot pain scores correlated positively with adiposity markers in obese children with flatfoot ( $\mathrm{P}=0.001)$.

In figure (1D) and table (2), there was a significant increase in the plasma levels of adiponectin, leptin, resistin, Il-6, and TNF- $\alpha$ in overweight $(\mathrm{P}=0.01)$ and obese $(\mathrm{P}=0.001)$ subjects compared to normal-weight subjects. Underweight subjects showed lower levels of the studied parameters, but the data obtained was not statistically significant $(\mathrm{P}=0.13)$. Subjects with flatfoot showed higher $(\mathrm{P}=0.001)$ levels of adiponectin, leptin, resistin, Il-6, and TNF- $\alpha$ compared to subjects with normal foot stance (Figure 1D).

In this study, younger age $(\beta=-0.256)$, male gender ( $\beta=-0.089)$, and overweight $(\beta=0.316)$ were closely related to flat foot incidence among obese subjects (table 2). Along with age and gender, adiponectin $(\beta$ $=0.125)$, leptin $(\beta=0.235)$, resistin $(\beta=0.136)$, Il 6 ( $\beta$ $=0.146)$, TNF- $\alpha(\beta=0.325)$, and BMI were also predictors of flatfoot $(\beta=0.258)$. The studied variables explained $65 \%$ of the variance among our schoolaged students.

In addition, our data showed that school children with obesity had a higher risk of flat foot (6.1 times; $\mathrm{P}=0.001$ ) and foot pain (8.5 times; $\mathrm{P}=0.001$ ), with significant increase $(p=0.005)$ in the level of adipocytes cytokines, as well as adiponectin, leptin, resistin, Il-6, and TNF- $\alpha$, compared to subjects with normal BMI (Table 2). Also, there were detrimental effects of foot pain (1.11 times; $\mathrm{P}=0.001)$ and flat foot (2.69 times;

TABLE 1. ANTHROPOMETRIC AND DEMOGRAPHIC MEASUREMENTS OF THE DIFFERENT POPULATION GROUPS OF A SAMPLE OF SCHOOLCHILDREN AGED 6-12YRS (MEAN \pm STANDARD DEVIATION).

\begin{tabular}{|c|c|c|c|c|c|c|c|c|}
\hline \multirow{3}{*}{ Parameters } & \multicolumn{8}{|c|}{ Boys $(n=220)$} \\
\hline & \multicolumn{2}{|c|}{$L W(n=14)$} & \multicolumn{2}{|c|}{$N W(n=126)$} & \multicolumn{2}{|c|}{$O W(n=30)$} & \multicolumn{2}{|c|}{$O B(n=50)$} \\
\hline & Mean $\pm S D$ & $95 \% \mathrm{Cl}$ & Mean $\pm S D$ & $95 \% \mathrm{Cl}$ & Mean $\pm S D$ & $95 \% \mathrm{Cl}$ & Mean $\pm S D$ & $95 \% \mathrm{Cl}$ \\
\hline Age (Years) & $9.9 \pm 0.8$ & $9.4-10$ & $10.1 \pm 0.8$ & $9.7-10$ & $9.6 \pm 0.8$ & $9.2-10$ & $10.3 \pm 0.8$ & $9.9-10.2$ \\
\hline Weight (kg) & $28.3 \pm 3.6^{\star *}$ & $25.1-29.2$ & $34.2 \pm 5.3$ & $32.5-36$ & $48.6 \pm 5.9^{* \star}$ & $39.2-52$ & $58.9 \pm 12.4^{\star \star \star}$ & $51.4-65$ \\
\hline Height (m) & $1.46 \pm 0.2$ & $1.4-1.49$ & $1.5 \pm 0.2$ & $1.47-1.6$ & $1.7 \pm 0.2^{\star \star}$ & $1.6-1.78$ & $1.79 \pm 0.2^{\star \star}$ & $1.76-1.9$ \\
\hline BMI (kg/m2) & $15 \pm 0.3^{\star *}$ & $14.6-15.4$ & $16.9 \pm 0.3$ & $16-17.2$ & $21.4 \pm 0.29^{\star \star}$ & $20.1-22$ & $26.5 \pm 3.6^{* * *}$ & $25.6-27$ \\
\hline$W C(\mathrm{~cm})$ & $54 \pm 4.8^{* *}$ & $52.6-55.3$ & $63.7 \pm 6.4$ & $62.7-64$ & $75.9 \pm 8.5^{\star \star}$ & 74.8-76 & $86.5 \pm 9.1^{\star \star \star}$ & $85.7-87$ \\
\hline$H P(\mathrm{~cm})$ & $61 \pm 3.7^{\star \star}$ & $60.8-62.3$ & $76.1 \pm 4.8$ & $75.7-77$ & $82.9 \pm 5.4^{* \star}$ & $81.8-84$ & $92.5 \pm 9.6^{* \star *}$ & $90.7-93$ \\
\hline WHR & $0.44 \pm 0.8^{* *}$ & $0.43-0.45$ & $0.48 \pm 0.8$ & $0.47-0.5$ & $0.54 \pm 0.8^{* *}$ & $0.53-0.6$ & $0.62 \pm 0.8^{* * *}$ & $0.63-0.7$ \\
\hline$W H t R$ & $0.48 \pm 0.3^{* *}$ & $0.47-0.49$ & $0.53 \pm 0.3$ & $0.5-0.54$ & $0.58 \pm 0.3^{* *}$ & $0.57-0.6$ & $0.69 \pm 0.3^{\star \star \star}$ & $0.68-0.8$ \\
\hline \multirow{3}{*}{ Parameters } & \multicolumn{8}{|c|}{ Girls $(n=330)$} \\
\hline & \multicolumn{2}{|c|}{$L W(n=16)$} & \multicolumn{2}{|c|}{$N W(n=164)$} & \multicolumn{2}{|c|}{$O W(n=50)$} & \multicolumn{2}{|c|}{$O B(n=100)$} \\
\hline & Mean $\pm S D$ & $95 \% \mathrm{Cl}$ & Mean $\pm S D$ & $95 \% \mathrm{Cl}$ & Mean $\pm S D$ & $95 \% \mathrm{Cl}$ & Mean $\pm S D$ & $95 \% \mathrm{Cl}$ \\
\hline Age (Years) & $9.9 \pm 0.8$ & $9.7-10$ & $10.3 \pm 0.8$ & $9.9-10.1$ & $9.8 \pm 0.8$ & $9.3-10.2$ & $10.2 \pm 0.8$ & 9.8-10.1 \\
\hline Weight (kg) & $28.6 \pm 3.8^{* *}$ & $26-29.4$ & $36.4 \pm 5.6$ & $35.8-37$ & $51.8 \pm 6.9^{* *}$ & $51.2-53$ & $62.9 \pm 11.2^{* * *}$ & $61.4-64$ \\
\hline Height (m) & $1.47 \pm 0.2$ & $1.4-1.49$ & $1.53 \pm 0.2$ & $1.51-1.6$ & $1.76 \pm 0.2^{\star \star}$ & $1.7-1.78$ & $1.8 \pm 0.2^{\star \star \star}$ & $1.76-1.9$ \\
\hline BMI (kg/m2) & $14.6 \pm 0.6^{* *}$ & $13.8-15$ & $17.2 \pm 0.7$ & $16-17.3$ & $21.6 \pm 0.29^{* \star}$ & $20.1-22$ & $26.9 \pm 3.4^{\star \star \star}$ & $26.1-28$ \\
\hline$W C(\mathrm{~cm})$ & $53.9 \pm 4.6^{\star *}$ & $52.6-55$ & $64.4 \pm 6.1$ & $63.7-65$ & $76.3 \pm 8.1^{\star \star}$ & $75.4-77$ & $84.7 \pm 8.9^{\star \star \star}$ & $83.7-86$ \\
\hline$H P(\mathrm{~cm})$ & $61.6 \pm 3.9^{\star *}$ & $60.5-63$ & $77.4 \pm 4.9$ & $76.8-78$ & $84.8 \pm 5.8^{* *}$ & $83.5-86$ & $93.8 \pm 9.8^{\star \star \star}$ & $91.5-95$ \\
\hline WHR & $0.44 \pm 0.8^{* *}$ & $0.4-0.44$ & $0.48 \pm 0.8$ & $0.46-0.5$ & $0.55 \pm 0.8^{\star \star}$ & $0.54-0.6$ & $0.60 \pm 0.8^{\star \star \star}$ & $0.62-0.6$ \\
\hline WHtR & $0.47 \pm 0.3^{* \star}$ & $0.46-0.5$ & $0.54 \pm 0.3$ & $0.51-0.6$ & $0.63 \pm 0.3^{\star \star}$ & $0.6-0.7$ & $0.67 \pm 0.3^{\star \star \star}$ & $0.65-0.7$ \\
\hline
\end{tabular}

Statistical analyses by One-way ANOVA with Dunnett post-hoc test. ${ }^{* *} \mathrm{p}<0.01,{ }^{* * *} \mathrm{p}<0.001$. LW, low weight; OW, overweight; OB, obesity; NW: normal weight; BMI, body mass index; WC, waist circumference; HP, hip circumference; WHR, waist to height ratio; WHtR: Waist-to-height ratio. 
$\mathrm{P}=0.001$ ) reported in subjects with low weight compared to normal subjects.

\section{DISCUSSION}

The findings of this study showed that foot pain was significantly associated with flat foot and adiposity markers in all subjects. The prevalence of flatfoot significantly (all $\mathrm{P}=0.001$ ) peaked at six, seven, and eight years of age for both boys and girls compared to older children, regardless of gender. Other studies had similar results, most of which on younger or infants and showing ratios of flatfoot. ${ }^{16-19,22-24}$ During childhood, age, gender, adiposity, and ligamentous laxity are considered the most predisposing factors and strongly determine the prevalence of flatfoot..$^{20-22}$

Overall, in this study, flatfoot was found in $30.4 \%$ of the study population. Boys had higher prevalence rates for flatfoot than girls (32.27 in boys vs28.8\% in girls; $\mathrm{p}=0.01$ ). Consistent with current results, previous research found flat foot in $52 \%$ of boys and $36 \%$ of girls aged 3-6 years old..$^{12,21-24}$

This study showed that $43.6 \%$ of the subjects had an abnormal change in BMI. The prevalence of increased BMI was 33.3\% in overweight and $62.5 \%$ in obese schoolchildren, respectively. Our results are consistent with other studies, which reported a relatively high prevalence of overweight, and obesity among children aged $6-12$ years. $^{12,14,15}$

In this study, BMI correlated positively with flat foot among school-age children. The prevalence for flatfoot was significantly higher in schoolchildren with obesity (52\%, $\mathrm{P}=0.001)$, overweight (31.25\%, $\mathrm{P}=0.01)$, and low weight (33.3\%, $\mathrm{p}=0.01)$ compared to the prevalence of flat foot $(17.2 \%)$ in children with normal weight. Consistent to our results, significant variations in the prevalence of flatfoot were reported in under-weight (13.9\%), normal-weight (16.1\%), overweight (26.9\%), and obese (30.8\%) schoolchildren aged 3-18 years. ${ }^{12,15}$ This may be explained by the fact that

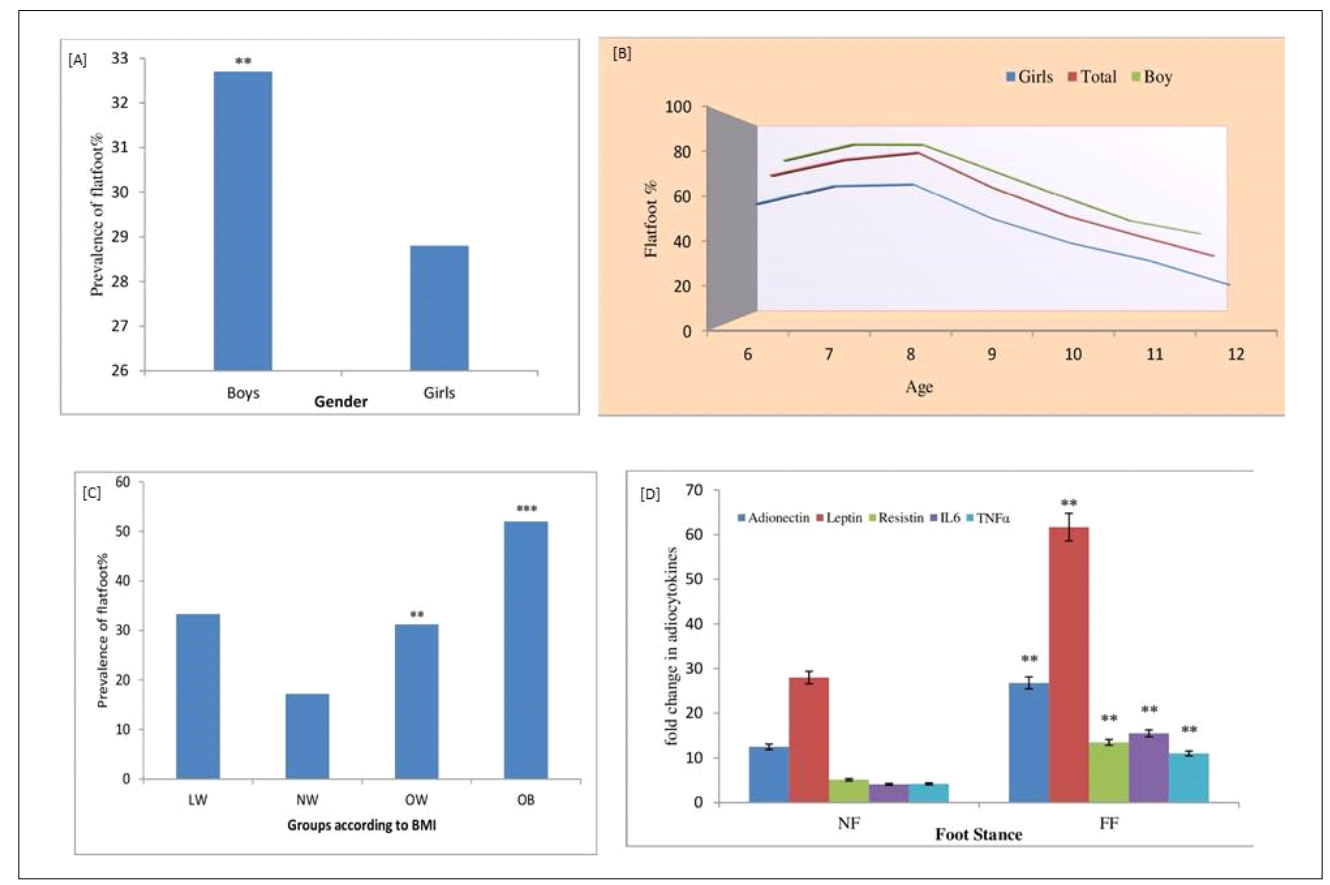

FIGURE 1. PREVALENCE OF FLATFOOT IN SCHOOL-AGE STUDENTS (6-12 YEARS) BASED ON GENDER [A], AGE [B], OBESITY [C], AND PHYSIOLOGICAL CHANGES IN ADIPOCYTOKINES AND INFLAMMATORY CYTOKINES [D]. STATISTICAL ANALYSES BY ONE-WAY ANOVA WITH DUNNETT POST-HOC TEST; TEST $(\neg \chi 2)$ WERE USED TO ANALYZE CORRELATIONS. HIGHER RATES OF FLAT FOOT WAS ESTIMATED IN BOYS ${ }^{* \star *} \mathrm{P}<0.01$ (BOYS VS. GIRLS) [A]. THE PREVALENCE OF FLATFOOT IN SCHOOLCHILDREN AGED 7 AND 8 YEARS WAS SIGNIFICANTLY HIGHER (ALL P=0.001) THAN IN CHILDREN WITH OLDER AGES REGARDLESS OF GENDER [B]. ALSO, STUDENTS WITH OVERWEIGHT AND OBESITY SHOWED HIGHER RATES OF FLAT FOOT COMPARED TO THOSE WITH LOW OR NORMAL WEIGHTS [C]. ${ }^{* *} \mathrm{P}=0.02,{ }^{* * *} \mathrm{P}<0.001$ (OW/OB VS LW OR NW), ${ }^{*} \mathrm{P}=0.01$ (LW VS NW). ALSO, ADIPOCYTOKINES AND INFLAMMATORY CYTOKINES SIGNIFICANTLY CORRELATED WITH FOOT STANCE [D]. ${ }^{* *} \mathrm{P}<0.001$ (FFVSNF). NORMAL FOOT (NF); FLAT FOOT (FF); LW: LOW WEIGHT; NW: NORMAL WEIGHT; OW: OVERWEIGHT; OB: OBESITY. 
TABLE 2. BETA REGRESSION COEFFICIENT ( $\beta)$, ORS ( $95 \% \mathrm{CI})$, AND P-VALUES FOR FACTORS EFFECT ON THE PROBABILITIES OF FOOT PAIN AND FLATFOOT IN SCHOOLCHILDREN WITH OBESITY.

\begin{tabular}{|c|c|c|c|c|c|c|c|c|c|}
\hline \multirow{2}{*}{ Parameters } & \multicolumn{3}{|c|}{ Low weight } & \multicolumn{3}{|c|}{ Overweight } & \multicolumn{3}{|c|}{ Obesity } \\
\hline & $\beta$ & OR $(95 \% \mathrm{Cl})$ & P-value & $\beta$ & OR $(95 \% \mathrm{Cl})$ & P-value & $\beta$ & OR $(95 \% \mathrm{Cl})$ & P-value \\
\hline Age & -0.256 & $1.2(0.6-1.5)$ & 0.01 & -0.135 & $1.1(0.86-1.3)$ & 0.01 & -0.245 & $1.0(0.9-1.3)$ & 0.01 \\
\hline Gender & -0.089 & $1.4(1.1-2.2)$ & 0.05 & -0.314 & $1.7(1.1-2.7)$ & 0.05 & -0.258 & $1.1(0.6-1.5)$ & 0.01 \\
\hline Weight & 0.316 & $2.1(1.1-3.4)$ & 0.01 & 0.224 & $1.3(1.1-1.8)$ & 0.01 & 0.315 & $1.5(1.1-1.6)$ & 0.01 \\
\hline $\mathrm{BMI}$ & 0.258 & $2.6(1.1-3.1)$ & 0.01 & 0.124 & $1.6(1.1-1.9)$ & 0.01 & 0.139 & $1.3(1.1-1.8)$ & 0.01 \\
\hline Foot Pain (Yes/No) & 0.125 & $1.11(0.8-1.7)$ & 0.001 & 0.321 & $3.2(1.8-7.6)$ & 0.003 & 0.345 & $8.5(4.5-11.6)$ & 0.001 \\
\hline Flat foot (Yes/No) & 0.235 & $2.69(3.5-5.8)$ & 0.001 & 0.145 & $4.8(3.1-8.2)$ & 0.005 & 0.128 & $6.1(3.5-9.1)$ & 0.001 \\
\hline Adiponectin, ng/mL & 0.136 & $2.1(1.8-4.3)$ & 0.05 & 0.321 & $1.8(1.1-3.2)$ & 0.01 & 0.215 & $2.9(1.5-3.2)$ & 0.005 \\
\hline Leptin, ng/mL & 0.146 & $1.5(1.1-2.3)$ & 0.01 & 0.324 & $1.2(0.94-2.4)$ & 0.05 & 0.124 & $3.7(2.94-5.1)$ & 0.005 \\
\hline Resistin, ng/mL & 0.325 & $1.18(0.8-2.5)$ & 0.01 & 0.324 & $1.5(1.1-2.9)$ & 0.01 & 0.384 & $1.6(1.1-3.2)$ & 0.005 \\
\hline IL-6, pg/mL & 0.450 & $2.3(1.2-3.7)$ & 0.05 & 0.314 & $3.7(2.9-4.9)$ & 0.05 & 0.131 & $3.1(2.9-5.6)$ & 0.005 \\
\hline $\mathrm{TNF}-\alpha, \mathrm{pg} / \mathrm{mL}$ & -0.256 & $1.45(1.2-2.9)$ & 0.03 & 0.245 & $1.4(1.1-2.8)$ & 0.04 & 0.214 & $1.9(1.3-3.6)$ & 0.005 \\
\hline$\Sigma \mathrm{R} 2(\%)$ & 0.135 & $35(28.6-45.7)$ & 0.001 & 0.425 & $62.7(48.9-75.1)$ & 0.001 & 0.512 & $65.7(56.7-86.4)$ & 0.001 \\
\hline
\end{tabular}

Entered variables to the model (multinomial logistic regression): $\Sigma R 2=$ summation of cumulative values of $R$ relating to studied variables. Adiponectin, leptin, resistin, IL-6, TNF- $\alpha$. IL-6, Interleukin- 6 cytokine; TNF- $\alpha$, tumor necrosis- $\alpha$ cytokine; ORs, odds ratios; $C l$, confidence interval; Beta regression coefficient ( $\beta$ ); BMI, body mass index. Hierarchical multiple regressions were used to estimate correlations

excess weight exerts more stress and load on the ligaments and soft tissues of the foot, which induces injuries and deformities in the feet. ${ }^{12-16}$

In our study, a significantly higher likelihood of flatfoot $(33.3 \%, \mathrm{p}=0.01)$ was reported in elementary school children aged 6-8 years old who were underweight, suggesting that underweight children were likely to have flatfoot, compared with those of normal weight (17.2\%). Similarly, a higher likelihood of flatfoot was reported in younger ages of underweight preschool children. ${ }^{12,17}$ Obesity was shown to be correlated with the incidence and development of foot pain. 2-9,12-16 $^{-16}$

The results of the current study showed that in overweight $(\mathrm{P}=0.01)$ and in obese $(\mathrm{P}=0.001)$ children with flatfoot, there is a significant increase in the levels of adiponectin, leptin, resistin, IL-6, and TNF- $\alpha$, in comparison to normal subjects. Similarly, a positive higher prevalence of foot pain with obesity was reported in young and adult subjects with flatfoot. ${ }^{\text {12-24 }}$ Pain and biomechanical changes in weight-bearing joints, such as the hip, knee, or foot structures were shown to be correlated with metabolic changes in adipokine profile, particularly higher levels of adiponectin and leptin. ${ }^{12,20-24}$

\section{CONCLUSION}

Foot pain showed an association with flat foot and childhood obesity in 30.4\% of school-age children (6-12 years). Foot pain was shown to correlate positively with the incidence of flat foot and changes in adiposity markers, such as adiponectin, leptin, resistin, Il-6, TNF- $\alpha$.

\section{Acknowledgement/Funding}

The authors are grateful to the Deanship of Scientific Research, King Saud University for funding through Vice Deanship of Scientific Research Chairs.

\section{Author Contributions}

Research idea, design, and practical work were proposed by GA. Review of literature was done by AR and AA. Data collection and analysis was executed by GA. Manuscript preparation and submission was done by GA. 


\section{RESUMO}

OBJETIVO: O objetivo deste estudo foi determinar a potencial associação de dor no pé e adipócitos plasmáticos como biomarcadores fisiológicos da obesidade infantil com incidência de pé plano em uma coorte de escolares egípcios de 6 a 12 anos.

MÉTODOS: Um total de 550 escolares egípcios (220 meninos e 330 meninas) com idades entre 6 e 12 anos foram convidados aleatoriamente para participar desta análise descritiva. Para todas as crianças, diagnóstico e gravidade do flatfoot, bem como adipócitos plasmáticos; adiponectina, leptina, resistina, IL-6 eTNF- $\alpha$ foram avaliados pelo método de Dennis e técnicas de imunoensaio, respectivamente. A dor no pé foi avaliada usando uma EVA padrão de 100 mm e a Faces Pain Scale, respectivamente.

RESULTADOS: O pé plano foi predito em 30,4\% das crianças em idade escolar; a maioria apresentou maior frequência de sobrepeso $(33,3 \%)$ e obesidade (62,5\%). Os meninos apresentaram maiores faixas de pé plano do que as meninas. A dor no pé correlacionou-se significativamente com pé plano e obesidade entre as populações estudadas. Em crianças obesas com sobrepeso, variáveis adipocitárias plasmáticas; adiponectina, leptina, resistina, IL-6 e TNF- $\alpha$ apresentaram correlação significativa com a postura do pé, em meninos e meninas. Além disso, as variáveis estudadas dos adipócitos, juntamente com o IMC, idade e sexo, explicaram cerca de 65\% da variância do pé plano com a dor entre os nossos alunos em idade escolar.

CONCLUSÃO: A dor no pé mostrou associação com pé plano e obesidade infantil em 30,4\% dos estudantes em idade escolar (6-12 anos). A dor no pé se correlacionou positivamente com a incidência de pé plano e a mudança nos marcadores de adiposidade; adiponectina, leptina, resistina, IL-6, TNF- $\alpha$.

PALAVRAS-ChAVE: Pé chato. Obesidade pediátrica. Doenças do pé. Biomarcadores. Obesidade/complicações.

\section{REFERENCES}

1. Fabry G. Clinical practice. Static, axial and rotational deformities of the lower extremities in children. Eur | Pediatr. 2010;169(5):529-34.

2. Labovitz JM. The algorithmic approach to pediatric flexible pes planovalgus. Clin Podiatr Med Surg. 2006;23(1):57-76.

3. Evans $A M$, Rome $K$, Peet $L$. The foot posture index, ankle lunge test, Beighton scale and the lower limb assessment score in healthy children: a reliability study. J Foot Ankle Res. 2012;5(1):1.

4. Villarroya MA, Esquivel JM, Tomas C, Moreno LA, Buenafé A, Bueno G. Assessment of the medial longitudinal arch in children and adolescents with obesity: footprints and radiographic study. Eur J Ped. 2009;168(5):559-67.

5. López-López D, García-Mira R, Alonso-Tajes F, López-López L. Análisis de la prevención podológica. Un estudio a través de Internet. Rev Int De Cien Podol. 2012;6(2):63-72

6. Chang JH, Wang SH, Kuo CL, Shen HC, Hong YW, Lin LC. Prevalence of flexible flatfoot in Taiwanese school-aged children in relation to obesity, gender, and age. Eur J Pediatr. 2010;169(4):447-52.

7. Abolarin T, Aiyegbusi A, Tella A, Akinbo S. Predictive factors for flatfoot: the role of age and footwear in children in urban and rural communities in South West Nigeria. Foot (Edinb). 2011;21(4):188-92.

8. Frey C, Zamora J. The effects of obesity on orthopaedic foot and ankle pathology. Foot Ankle Int. 2007;28(9):996-9.

9. Das UN. Is metabolic syndrome $X$ an inflammatory condition? Exp Biol Med (Maywood). 2002; 227(11):989-97.

10. Cheng |C, Leung SS, Leung AK, Guo X, Sher A, Mak AF. Change of foot size with weightbearing. A study of 2829 children 3 to 18 years of age. Clin Orthop. 1997;(342):123-31.

11. Haider DG, Holzer G, Schaller G, Weighuber D, Widhalm K, Wagner O, et al. The adipokine visfatin is markedly elevated in obese children. J Pediatr Gastroenterol Nutr. 2006;43(4):548-9.

12. Pourghasem M, Kamali N, Farsi M, Soltanpour N. Prevalence of flatfoo among school students and its relationship with BMI. Acta Orthop Traumatol Turc. 2016;50(5):554-7.

13. Cetin A, Sevil S, Karaoglu L, Yucekaya B. Prevalence of flat foot among elementary school students, in rural and urban areas and at suburbs in
Anatolia. Eur | Orthop Surg Traumatol. 2011;21(5):327-31.

14. Gruodytė R, Jürimäe J, Cicchella $A$, Stefanelli $C$, Passariello $C$, Jürimäe T. Adipocytokines and bone mineral density in adolescent female athletes. Acta Paediatr. 2010;99(12):1879-84

15. Leoni MC, Valsecchi C, Mantelli M, Marastoni L, Tinelli C, Marchi A, et al. Impact of child obesity on adipose tissue physiology: assessment of adipocytokines and inflammatory cytokines as biomarkers of obesity. Pediatr Rep. 2010;2(2):e19.

16. Cole TJ, Bellizzi MC, Flegal KM, Dietz WH. Establishing a standard definition for child overweight and obesity worldwide: international survey. Br Med J. 2000;320(7244):1240-3.

17. Ashwel M, Lejeune $S, M c P h e r s o n ~ K$. Ratio of waist circumference to height may be better indicator of need for weight management. BM]. 1996;10:312(7027):377

18. Ramírez-Vélez R, Anzola A, Martinez-Torres |, Vivas A, Tordecilla-Sanders A, Prieto-Benavides D, et al. Metabolic syndrome and associated factors in a population-based sample of schoolchildren in Colombia: the FUPRECOL Study. Metab Syndr Relat Disord. 2016;14(9):455-62.

19. Siervo M, Prado CM, Mire E, Broyles S, Wells |C, Heymsfield S, et al. Body composition indices of a load-capacity model: gender- and BMI-specific reference curves. Public Health Nutr. 2015;18(7):1245-54.

20. Suárez-Ortegón MF, Ramírez-Vélez R, Mosquera M, Méndez F, Aguilar-de Plata C. Prevalence of metabolic syndrome in urban Colombian adolescents aged 10-16 years using three different pediatric definitions. J Trop Pediatr. 2013;59(2):145-9.

21. Denis A. Pied plat valgus statique. Encyclopedie Medico-Chirurgicale Appareil Locomoteur. Paris: Editions Techniques;1974.

22. Aicher B, Peil H, Peil B, Diener HC. Pain measurement: Visual Analogue Scale (VAS) and Verbal Rating Scale (VRS) in clinical trials with OTC analgesics in headache. Cephalalgia. 2012;32(3):185-97.

23. Szyfelbein SK, Osgood PF, Carr DB. The assessment of pain and plasma beta-endorphin immunoactivity in burned children. Pain. 1985;22(2):173-82.

24. Ghaderi F, Banakar S, Rostami S. Effect of pre-cooling injection site on pain perception in pediatric dentistry: "A randomized clinical trial". Dent Res | (Isfahan). 2013;10(6):790-4. 